This is an electronic reprint of the original article. This reprint may differ from the original in pagination and typographic detail.

Author(s): Arpiainen, Riitta-Liisa; Tynjälä, Päivi

Title: Introducing Team Learning in a Developing Economy : Students' Experiences of Experiential Entrepreneurship Education in Namibia

Year: $\quad 2017$

Version:

Please cite the original version:

Arpiainen, R.-L., \& Tynjälä, P. (2017). Introducing Team Learning in a Developing Economy : Students' Experiences of Experiential Entrepreneurship Education in Namibia. Journal of Enterprising Culture, 25(2), 179-210.

https://doi.org/10.1142/S0218495817500078

All material supplied via JYX is protected by copyright and other intellectual property rights, and duplication or sale of all or part of any of the repository collections is not permitted, except that material may be duplicated by you for your research use or educational purposes in electronic or print form. You must obtain permission for any other use. Electronic or print copies may not be offered, whether for sale or otherwise to anyone who is not an authorised user. 


\section{INTRODUCING TEAM LEARNING IN A DEVELOPING ECONOMY: STUDENTS' EXPERIENCES OF EXPERIENTIAL ENTREPRENEURSHIP EDUCATION IN NAMIBIA}

"We did not just become classmates, we became a family"

\section{RIITTA-LIISA ARPIAINEN}

Tampere University of Applied Sciences and Aalto University, Business School, Finland

$$
\begin{gathered}
\text { riitta-liisa.arpiainen@tamk.fi } \\
\text { PÄIVI TYNJÄLÄ } \\
\text { University of Jyväskylä, Finland } \\
\text { paivi.tynjala@jyu.fi }
\end{gathered}
$$

Keywords: team, learning environment, experiential entrepreneurship education, developing economies

Entrepreneurship is considered to be a driving force behind nations' economic development, and entrepreneurship education's role is essential in shaping entrepreneurial attitudes, skills and culture. The objective of this study was to investigate students' experiences of entrepreneurship education in a developing economy, especially as regards learning in and through teams. The research project was conducted in Namibia, where the challenges to breaking out of poverty are huge. Methodologically, the study was based on qualitative thematic analysis of semi-structured interviews (2009-2014) of higher education students $(N=13)$ taking part in an action-based, experiential entrepreneurship programme. In the analysis of students' teamwork experiences, five main themes related to learning in and through teams emerged - the first three relating to individuals, the fourth to the team, and the fifth to wider social relations: (i) psychological safety, (ii) tolerance of uncertainty, (iii) strengthening of self-efficacy, (iv) strengthening of team efficacy, and (v) understanding of others and other cultures. The outcomes may be utilised in establishing, developing and planning similar entrepreneurship education programmes across different cultural settings in developing economies. 


\section{INTRODUCTION}

"Coming together is a beginning, staying together is progress, and working together is success.”(Henry Ford)

Current societies are often characterised by continuous change, which is rapidly altering the conditions in organisations all around the globe. This also raises challenges for the work of educational institutions, which are expected to prepare the future workforce to be able to cope with continuous change and uncertainty and, at the same time, act as change agents (e.g., Barnett, 2004; Tynjälä et al., 2012). Governments' expectations of the education system are especially high in developing economies, such as in African countries, because education is widely recognised as an important tool for promoting economic growth (Barro, 2013). Africa's paradox is that it is one of the richest continents in the world, yet most Africans are poor (Maathai, 2009). Empirical research indicates that besides education, entrepreneurship has been the driving force behind nations' economic development (Schumpeter, 1950; Baumol, 1968, 1990; Christensen et al., 2002; Bruton et al., 2013). Therefore, the role of entrepreneurship education and training in shaping individual attitudes, actions and ambitions highly interests policymakers, educators and practitioners (Martínez et al., 2010). The importance of entrepreneurship education and training was also stressed in a recent (2009) report by the Global Education Initiative (GEI) of the World Economic Forum (World Economic Forum, 2009).

Over the years, Global Entrepreneurship Monitor (GEM) researchers (Herrington \& Kelly, 2012) have found a positive correlation between the success rate and sustainability of early-stage entrepreneurs and the level of education attained. In all African Sub-Saharan countries, participating in their study, the level of education in general was low and special entrepreneurship education was practically nonexistent. The GEM researchers call for a stronger focus on entrepreneurship as a life skill to be taught in schools, in order to foster problem-solving skills and self-confidence that will benefit young people (Herrington \& Kelly, 2012). Current macrolevel conditions in Africa seem to be conducive to this goal of enhancing entrepreneurship, as the African business environment has changed rapidly in the last decades, giving way to rising entrepreneurship (Eijdenberg et al., 2013).

While organising entrepreneurship education for young people is globally called for, in entrepreneurship education literature the educational practices regarding this field are often criticised as being overly traditional, and it has been stated that current entrepreneurship teaching is more a matter of method than content (Vesalainen \& Strömmer, 1998; Carrier, 2005). Numerous recommendations can be found with regard to how to enhance entrepreneurship teaching practices. For example, courses to develop negotiation, leadership, creative thinking and opportunity discovery skills (McMullan \& Long, 1987), as well as action learning practices (Gartner \& Vesper, 1994) and the life-story approach (Rae \& Carswell, 2000), have been suggested for developing entrepreneurship pedagogy. Man (2007) emphasised the need for the context to stimulate entrepreneurship learning and reflection on learning instead of only providing specific skills or knowledge.

Team learning has been presented as one response to calls for renewing educational practices in general, and in entrepreneurship education in particular. Many scholars have emphasised the significance of effective teams in organisations and regard these as essential learning units (Senge,1990; Edmondson, 2002; Decuyper et al., 2010). For this reason, it is often suggested that team learning can also prepare students for real-world experiences and can function as an important learning tool when dealing with the complexity and rapid changes in today's societies (Yazici, 2005). Group learning, team learning, collaborative and co-operative learning are often 
used as parallel concepts in the literature. For example, Edmondson and colleagues (2001) define group learning as a process where a group takes actions, acquires and shares knowledge, reflects upon feedback, and adapts or improves its actions. Similarly, according to Decuyper and colleagues (2010), team learning is a process where team members work collectively to achieve a common goal as a group. Without team members' commitment and effort, working and learning in a team may fail.

Lorz and colleagues (2013) suggest that, in entrepreneurship education, the effectiveness of different types of pedagogies should be tested. Although team learning could be an effective tool for individuals to enhance their entrepreneurial and enterprising mindset and spirit, only a few studies on entrepreneurship education have focused on teams as a learning environment or on collective perspectives in learning (McKeown, 2015). In particular, there is limited understanding of entrepreneurship education in developing economies, where the application of non-traditional teaching methods, such as team learning, may subsequently be especially challenging. Therefore, the purpose of the present study was to examine how students experience team-based learning in a developing economy.

The context of the current study is Namibia, which is a culturally diverse multi-ethnic society. Namibia has a population of around 2,403,000 (World Bank, 2015) and is comprised of eleven major ethnic groups (Languages of Namibia, 2013). English is used as the official language, though Afrikaans is another widely spoken language (Ministry of Health and Social Services, Namibia, 2001). Namibia, as a rather newly independent country, carries a strong memory of the past: it was a colonised country and apartheid brought with it great restrictions on the rights of the population based on race, ethnicity, class, gender, and language (Suonpää, 2010). The long history of colonialism has substantially influenced the cultural profile of Namibia (Middleton \& Miller, 2008). According to a GEM report (Herrington \& Kelly, 2012), the most problematic factors in Namibia for doing business are the insufficiently educated workforce, access to finance and corruption. Namibia has one of the highest rates of GDP (Gross Domestic Product) per capita among the Sub-Saharan countries in Africa, but it also ranks as one of the most unequal societies in the world in terms of income and wealth: a Gini coefficient of 0.6 versus an average of 0.43 for all middle income countries (MIC) (UNDP, 2009). Unemployment is one of the main reasons for the unequalities in Namibian society (Namibia Labour Force Survey, 2010). Particularly, the unemployment rate of youth has become a matter of concern on the national level: $64.3 \%$ of $15-$ 19-year-old, $50.6 \%$ of 20-24-year-old, and 33.3\% of 25-29-year-old Namibians are unemployed (Namibia Statistics Agency, 2015). Consequently, the most important challenge for Namibia is to overcome poverty and inequality.

Because we researched the potential of entrepreneurship education that uses modern pedagogical solutions in the context of a developing economy, the objective of our study was to produce knowledge about learning in and through teams in the developing economy in order to identify and understand the role of the team in the learning process. Specifically, the following research question was addressed:

How do students experience team learning in entrepreneurship education within their developing economy?

In the following sections, we first discuss topical challenges related to entrepreneurship education in general and team learning in particular. This is followed by a description of our empirical study and its results. Finally, we discuss the implications our findings for research and practice. 


\section{ENTREPRENEURIAL LEARNING AND ENTREPRENEURSHIP EDUCATION}

It has been stated that entrepreneurship itself is a learning process; it entails the ability to cope with problems and to learn from the problems. For example, Minnity and Bygrave (2001) have suggested that entrepreneurship can be seen as a process of learning, and that a theory of entrepreneurship also needs a theory of learning. Entrepreneurial learning has been described as involving actions and experiences (Gartner, 1988; Minniti \& Bygrave, 2001). Mistakes, crises and failures in entrepreneurial learning, such as in 'critical learning events', simulate the entrepreneur's challenges and are a part of transformative learning (Deakins \& Freel, 1998; Cope, 2003). Coping with uncertainty (Pittaway \& Cope, 2007a), opportunity recognition and problem solving (Young \& Sexton, 1997; Minniti \& Bygrave, 2001), and reflection on experience (Kolb, 1984; DeFilippi, 2001) have also been mentioned as essential elements of entrepreneurial learning. Intentionality (in this case, the intention to act in an entrepreneurial way) and selfefficacy are fundamental learning concepts in entrepreneurship education as they explain how experiential learning can be enhanced by increasing confidence and intent (Pittaway et al., 2010). It has also been argued that entrepreneurial learning should be seen as a social phenomenon (Cope, 2005; Rae, 2002), where trust, respect and shared experiences have an impact on the quality of learning (Deakins et al., 2000). According to Rae (2005), entrepreneurial learning helps the student 'to recognise and act on opportunities and interact socially to initiate, organise and manage ventures'. The question of whether entrepreneurship can or cannot be taught can be seen as irrelevant today, since it has been proven that it can indeed be taught (e.g., Henry et al., 2005; Kuratko, 2005); the challenge, rather, is choosing the appropriate teaching methods.

Learning theories offer several understandings of the role of learning in entrepreneurship. For example, Kolb's (1984) model of learning as an experiential process is widely used in entrepreneurship education. The model describes learning as a cycle consisting of four phases: 1) concrete experience; 2) observation and reflection; 3) formation of abstract concepts and generalisations; 4) and testing implications of concepts in new situations. The reflection on experience leads to understanding and future actions, leading to a cumulative spiral of experiential learning (Kolb, 1984). In line with the experiential learning theory, traditional ways of teaching, such as lectures, have been seen as inadequate for entrepreneurship education (Gibb, 2002a), whereas the action-oriented approach is considered to stimulate the individual's action, rationality and capability, which are needed in entrepreneurship (Johannisson et al., 1998; Gibb, 1987, 2002b; Deakins \& Freel, 1998). According to Honig (2004), students need to be taught to be prepared for novelty and surprise in entrepreneurial education, as that will be the environment they will be facing. For example, the incorporation of experiential trial and error will allow students to be better prepared for approaching entrepreneurial events upon graduating, and the students learn to maximise failure as a learning experience. Honig (2004) suggests that the outcomes of experiential trial and error experiences in learning processes are self-confidence, risk-tolerance, and leadership and managerial experience.

Bandura's (1986) social cognitive theory and his concept of self-efficacy (Bandura, 1997) have also been used in entrepreneurship education contexts. Self-efficacy is defined as a person's confidence in his or her ability to perform a specific task, influencing the motivation and ability to engage in specific activities (Bandura, 1997). High self-efficacy has also been associated with risk-taking and opportunity recognition (Krueger \& Dickson, 1994), both of which are important elements of entrepreneurship (Schumbeter, 1950; Kyrö, 2007; Rae 2007). According to the social cognitive theory, self-efficacy is established and enhanced in four ways: i) enactive mastery; ii) vicarious experience (role modelling); iii) subjective norm (social persuasion); and iv) psychosocial states (Wood \& Bandura, 1989). According to Chen and colleagues (1998), 
entrepreneurial self-efficacy signifies that an individual has confidence in his or her ability to perform entrepreneurial tasks and roles successfully. When group members engage in common, valued activities together, they may experience common, collective efficacy (Bandura, 2000). Team-efficacy (Bandura, 1997) can be defined as a team's perceived capability to organise and execute actions required to reach the set common team goals (Kozlowski \& Ilgen, 2006).

A wide range of attitudinal, motivational and personality factors like self-efficacy, confidence, motivation to achieve, and decisiveness have been identified as playing a remarkable role in entrepreneurial learning (Rae \& Carswell, 2001; Fenwick 2003). The emotional aspect also plays an essential role (Arpiainen et al., 2013), critical incidents being significant emotional events in entrepreneurial learning (Cope \& Watts, 2000). Based on her field study, Edmondson (1999) has introduced the construct of team psychological safety, where the team members share their belief that the team is a safe environment for interpersonal risk-taking. Edmondson's study also found that team psychological safety has an influence on learning behaviour, which in turn impacts team performance.

In research on the entrepreneurial learning of a small firm's management team (McKeown, 2010, 2012a, 2012b, 2015), the shared learning climate was found to be characterised by trust, transparent leadership, shared reflective practice, a willingness to challenge assumptions, learning from mistakes, and engaging in networks beyond the team. Further, sustained and reflective dialogue, that is, communication and the art of listening and reflection within the team allowing collective understanding to be adopted, was found to be essential in team learning. McKeown (2015) states that team learning is not the sum of the cognition of the team members, it is rather a shared understanding of business, motivation, opportunities, commitment, reflection and dialogue, leadership style, trust, and the transparency of the team or the company.

In their studies of university students' entrepreneurship clubs and societies, Pittaway and colleagues (2010) found that increased action leads to reflective practice, and there social learning is important. The collaborative learning environment supported learning and the students had plenty of opportunities to experiment with their skills without major risks. The study highlights the capacity of entrepreneurship education to simulate entrepreneurial learning, illustrating the value of university students' entrepreneurship clubs and societies and also explaining why students engage in them.

Hytti and colleagues (2010) studied perceived learning outcomes in entrepreneurship education, especially regarding student motivation and team behaviour. They found that both intrinsic and extrinsic motivation, as well as team behaviour, are important agents influencing learning outcomes. According to their research, team behaviour moderates the relationship between intrinsic motivation and learning outcomes. So, learning in teams in an entrepreneurship course seems to produce more positive outcomes for students with both low and high intrinsic motivation, but especially for the latter student group. In her research of teachers' entrepreneurial competences, Peltonen (2014) found that collaborative learning can help teachers to adopt a more entrepreneurial teaching approach and that an empowering learning environment, collaborative learning and reflection play an important role in developing entrepreneurial competences. Futhermore, in another study, on Estonian engineering students' entrepreneurship course, collaborative team learning was found to play a central role in entrepreneurial learning, teams being the main source for dealing with difficult tasks and time-related issues and also for support to overcome negative emotions (Täks, 2015). It has also been perceived that learning entrepreneurship in teams is an emotionally challenging way of learning (Arpiainen et al., 2013). 


\section{TEAM LEARNING IN EDUCATION}

Recently, there has been growing interest in team learning both in the field of education and in society overall. A collaborative work environment seems to become the norm for every organisation (Decuyper et al., 2010; Edmondson, 2013). Future employees are expected to move from narrow work tasks to broader work roles, from narrow competence to extensive multicompetences, from individual work roles to groups and teams, and also to learn from others and to effectively utilise others' know-how and thoughts (Hanhinen, 2010). Education is often seen as an important context for students in which to acquire collaborative skills before entering the labour market (Vangrieken et al., 2015). As a result, there has been fast growth in the use of small groups in college-level learning during the last two decades (Fink, 2002).

The concept of team learning is based on two main research lines: first, on organisational learning theories (e.g., Argyris \& Schön, 1974; Kolb, 1984; Nonaka \& Takeuchi, 1995; Senge, 1990); and, second, on studies concerning collaborative learning (e.g., Bruffee, 1999; Johnson DV, Johnson RR \& Smith, 1991; Michaelsen, 1983; Michaelsen, Black, \& Fink, 1996; Hemetsberger \& Reinhard, 2006). Co-operative learning, group learning, collaborative learning and peer learning, for example, represent similar pedagogical solutions. Common to these approaches is learning together and sharing knowledge and experiences with others. In the early work in the field of co-operative learning, Johnson DV and Johnson RR (1987; see also Johnson et al., 1991) defined positive interdependence, individual accountability, face-to-face interaction, social and small group skills, and group processing as the essential elements of co-operative learning. Peer learning is a broader conceptual umbrella, which includes co-operative and collaborative learning, peer tutoring and other forms of learning with peers. Improvements in interaction, respect and relations with other learners have been said to be potential benefits of peer learning (O'Donnell, 2006). The concept of team-based learning was first introduced by Larry Michaelsen in the late 1970s to support classroom learning at the University of Oklahoma (Michaelsen et al., 2002). Nowadays, team-based learning is extensively applied in business courses in Western countries, as it is assumed to enhance learning and the teamwork skills of students (Umble et al., 2008). In the USA, many state and national standards of curricula include recommendations for the use of groups to enhance, for example, critical thinking and conceptual understanding. The benefits of team-based learning are claimed to be improved learning outcomes (Koles et al., 2010), deeper student engagement (Haidet et al., 2012), improved problem-solving skills (Kelly et al., 2005), and better communication and teamwork skills (Thompson et al., 2007). To be able to learn effectively, a team needs to have a clear vision of where it stands and common goals that are to be reached, as well as methods for how to reach the set goals (Decyper et al., 2010).

Sessa and London have introduced a theory of continuous group learning (Sessa \& London, 2006; London \& Sessa, 2006a, 2006b). In this group model, learning is caused by external forces, such as pressures of limitations and opportunities (e.g., tight schedules, high expectations, a shortage of resources), as well as internal forces, such as the vitality of the group leader or group members, and a desire to set new goals or develop new methods. The readiness to learn at the group level is a function of the group's maturity, how group members contribute to the group, and how the members experience working with other group members. In groups, where the members feel interpersonal trust (psychological safety), they are more willing to share knowledge and develop ideas. Sessa and London (2008) have defined three types of group learning: adaptive, generative, and transformative. In adaptive learning, the group is responding to a pressure or 
opportunity and an adjustment to a change can happen automatically in a group without bigger plans. In generative learning, the group is searching for new knowledge, studying new skills, and then implementing them. This type of learning can happen when the group is ready to learn. When transformative learning appears, the goals, structure or activities of the group will change significantly. In addition to the readiness for learning, this form of learning requires powerful triggers in the environment, which demand transformation.

Team learning is recently being advocated in entrepreneurship education, where it is often stated that students usually learn best when they work in teams and share and reflect on their learning experiences with their peers (Raelin, 1997; DeFilippi, 2001; Pittaway \& Cope, 2007b). It is also assumed that team learning can prepare students for real-world experiences and can function as an important learning tool when dealing with the complexity and rapid changes of today's societies (Yazici, 2005). Previous studies on team-based entrepreneurship education in Western cultures have shown that students find it challenging but also useful for their skill development (e.g., Täks et al., 2014, 2016). Because of societal and cultural differences, the generalisability of these findings to the developing economies is questionable, and therefore, in the present study, research on team learning in entrepreneurship education is extended to the developing country.

\section{METHODOLOGY}

The subject of the present study is the entrepreneurship study programme called 'ProLearning in Namibia', which started in March 2009 at the Polytechnic of Namibia. The learning model of the action-based, experiential ProLearning study programme is based on the Finnish Tampere University of Applied Science entrepreneurship study programme model (Lilischkis et al., 2015). Namibian students, mainly from the School of Business and Management, studied five years for a Bachelor's degree with Honours the last two years of which were completed under the ProLearning entrepreneurship programme. The first three years provided a common foundation of skills and knowledge in business, counting as a standard Bachelor's degree. The purpose of the new entrepreneurship programme at the Polytechnic of Namibia was to establish a modern working model for promoting entrepreneurship through student teams forming co-operative companies, engaging in self-employment and striving for personal and corporate growth. The programme goals were to enhance students' entrepreneurial skills, knowledge, thinking and attitudes, including opportunity-seeking, initiative-taking, independent and responsible working habits, problem solving, commitment to work, ability to cope with uncertainty, risk-taking, selfawareness, self-confidence, persuasiveness, creativity, negotiating skills, skills in giving and getting feedback, and commitment to achievement. The students applied for this entrepreneurship programme by sending in a letter of motivation, explaining why they would like to study entrepreneurship in this programme, and they were then selected based on the subsequent individual interviews.

Fundamentally, the learning environment was based on learning-by-doing and Kolb's (1984) theory of experiential learning. Thus, concrete actions are implemented, observed and reflected upon, and then abstractions are made and tested in new situations. By combining different sources of explicit knowledge - for example, reading books, attending seminars and comparing, applying and refining one's own theories - new explicit knowledge is created. This knowledge needs to be tested again in real-world cases and projects for further reflection and discussions of the internalised experiences (Leinonen et al., 2004; Tynjälä, 2008; Tynjälä \& Gijbels, 2012). At 
the beginning of their entrepreneurship studies, the participating students $(N=13)$ set up a team to run a co-operative company and defined what kind of business they were going to exercise. They also defined their company's values, mission and goals, as well as the team rules. Usually, students started their team business by undertaking small projects that did not require money, and then they moved to bigger and more challenging projects. Thus, they learned by doing and developing in the team context. During their two years of entrepreneurship studies, the team had around 20 major customer projects, such as Namibia's 20 $0^{\text {th }}$ Independence Celebration Corporate Float (2010) for the Polytechnic of Namibia; a Co-operative Networking Week for the Division of Co-operative Development (DCD) at the Ministry of Agriculture, Water and Forestry with support from the Namibia Development Trust (NDT); the Ongwediva Annual Trade Fair 2010 for the Namibia Business Innovation Centre (NBIC); AIDS Week for the Ministry of Education (HAMU department), and a Standard Bank Market Student Activation Road Show (2009 \& 2010) for Standard Bank.

Instead of lectures and exams, the learning process was to a large degree self-determined, supported by coaches. The process included reading the latest professional books and theories relating to organisational and situated learning (Lave \& Wenger, 1991), as well as different learning tools such as innovation sessions, feedback sessions, learning contracts, projects and book essays. In addition to the real-world projects, the studies featured regular team meetings, small group workshops and coaching. Independent learning was also an important element of the students' studies. All of the students read 60-70 books during their entrepreneurship studies, wrote essays combining theory and practice that reflected what they had learned thus far, and discussed these in team meetings. The students were allowed and encouraged to learn not only from their successes but also from their mistakes and failures. In the ProLearning programme, the dialogue taking place in team sessions twice a week for four hours is seen as the most important tool for reflecting on experiences, developing new ideas and sharing these. In the weekly team sessions, the students learned by giving and getting both positive and corrective feedback. The students had freedom and carried responsibility at the same time in setting themselves meaningful, individual learning goals. Instead of taking a final exam, the students carried out a team-based customer project lasting 24 hours, at the end of the study programme.

The data for the study were gathered through semi-structured interviews in Winhoek, Namibia, in March 2009 and March 2014. The students $(N=13 ; 7$ male, 6 female) of the ProLearning entrepreneurship study programme's first 'team company' at the Polytechnic of Namibia were followed from the beginning to the end of their entrepreneurship studies and also after graduation. The individual interviews (approximately 30-60 minutes each) were conducted by the first author at the beginning, in the middle and at the end of the studies with all thirteen students. The individual post-education interviews were conducted in Namibia, August 2012 and March 2014; twelve students participated. Altogether, the data consisted of 61 interviews. The interviews were recorded and transcribed verbatim.

The interview questions included the following themes:

- Comparison of the entrepreneurship programme with other courses $\square$ Issues that were handled during the programme

- Discussion of the students' role as a learner during the programme 
- Team learning, learning in a team, personal learning, motivation, relations, and emotions about their entrepreneurship and entrepreneurial learning experience during the programme

- Expectations and reservations of the learner regarding this kind of learning

In the first three interviews, the questions were mostly the same in order to assess possible changes and developments over time. In the last two interviews, following the students' graduation, the participants were asked to look back at their studies and experiences, especially in relation to their present jobs, their personal viewpoints on entrepreneurship, and their fears and dreams. The students were 20-31 years old when they started in the entrepreneurship programme, in February 2009, and had already studied mainly at the School of Business and Management of the Polytechnic of Namibia for three years. 8 out of 13 students had some association with entrepreneurship through relatives. The 13 students represented 7 different ethnic groups of Namibia.

The first author also had several informal discussions with the team members and participated in several team meetings and team dialogues in Namibia, between 2009 and 2014. In that way, the researcher got to know and understand the talk of the students better. This information was used as the background data for the research to support the analyses and interpretation of the data.

The overall aim of the research was to find out how students experienced the role of learning entrepreneurship as part of a team, involving risk-taking and insecurity, which was new to them. The learning culture in Namibian higher education is based on traditional, lecturer-centred teaching, and therefore it was important to examine students' perceptions of non-traditional, action-based team learning.

\section{Data analysis}

A thematic analysis (Ryan \& Bernard, 2003; Braun \& Clarke, 2006) was applied in examining the data. According to Braun and Clarke (2006), the rationale for choosing this methodological approach enables the provision of rich and detailed qualitative data that can be used within different theoretical frameworks.

In the present study, we examined how students experienced team learning in entrepreneurship education, in a developing economy. To identify the experiences of the students from the data, the authors followed the six-phase model of thematic analysis by Braun and Clarke (2006), as follows: 1) familiarising oneself with the data, 2) generating initial codes, 3) searching for themes, 4) reviewing themes, 5) defining and naming themes, and 6) producing the report.

The analysis of the present research was carried out by its two authors in three main phases. The first phase of our analysis focused on identifying and describing the participants' experiences of team learning in their entrepreneurship education in general terms. First, to assess possible similarities between the students' experiences, the transcribed interviews were read carefully as a whole, several times, by the first author. Then, by iteratively moving back and forth between the coded data, the first author identified the most important areas of the team learning experiences according to similarities in these found throughout all of the data. Next, the responses in the interviews were grouped into meaningful categories. After that, the first author formed the first draft of the qualitatively differing themes. A preliminary theme was formed whenever there was enough evidence for it. The second phase of the analysis was undertaken in collaboration between the two researchers, examining the categories (preliminary themes) based on the students' 
original quotations until they agreed on the main themes of students' experiences of team learning. As a result of this systematic, iterative analysis, the students' experiences of learning in and through team were classified into five main themes. In the third phase of the analysis, the authors examined the relationships between the categories based on the original extracts from the data. The associations that were found between the categories were illustrated with arrows, as presented in Figure 1.

\section{RESULTS}

The participating entrepreneurship students' experiences of team learning could be divided into five main themes:

(i) psychological safety, (ii) tolerance of uncertainty, (iii) strengthening of self-efficacy, (iv) strengthening of team-efficacy, and (v) understanding of others and other cultures. The first three themes related to individuals, the forth to the team, and the fifth to wider social relations.

\section{Psychological safety}

As the team was the most important environment, functioning as the 'playing field' of learning in the ProLearning programme, the team became very meaningful to its members, in Namibia. The families and relatives of many of the students lived in remote villages in the countryside, and the ProLearning students experienced the team members' support and encouragement to be extremely important during their learning process in this totally new learning environment, especially at the beginning of their entrepreneurship studies. The first theme recognized in the data reflects this supportive role of the team and was labelled psychological safety in the team. Whilst learning together as a team for two years and sharing a lot of experiences and feelings, both positive and negative, the team members learned to trust each other, which positively affected team members' self-esteem and self-belief. This, in turn, positively affected their success, accomplishing their common tasks and reaching their goals. The regular weekly team meetings with open and honest dialogue supported by the team coach, reflections of successes and failures of team projects, and positive and constructive feedback for each other were the main factors building up strong psychological safety in the team. The following quotes (all quotes are verbatim) characterising students' experiences are examples of the team's psychological safety:

\footnotetext{
"I think that one of the best things about this programme is that you have this safety of the whole team to fall back on with your ideas." (m4)

"But having twelve people around you that believe in you, that know you can do something, it's more than enough - twelve people are a lot. And the fact that they can trust you — what they say is important - that: you can do this and we are behind you no matter what mistakes you make." (f1)

"We always stand up for each other-something that did not happen when we were on the other side [conventional studies]; and we are becoming more of a family because now, nowadays, we call each other sister, brother - the love is there, the spirit is there." (m6)
}

\section{Tolerance of uncertainty}

During their team studies, the students experienced a lot of pressure and insecurity coming from both inside and outside the programme. A possible reason for these pressures was the novelty of the programme and the innovative and unfamiliar way of studying compared to the traditional, 
lecturer-centred way, which is the main approach used in higher education in Namibia. The students felt a lot of uncertainty, because many of the personnel and other students outside the programme had strong doubts concerning this way of studying entrepreneurship. Most of the students were not familiar with each other before joining the team in this entrepreneurship programme. Many of the students also felt the support from the school's management to be insufficient. Further, the students were representing seven different ethnic groups, with different habits and ways of understanding the world and doing things, which also caused uncertainty and insecurity, especially at the beginning of their studies. The students were also uncertain about the theoretical grounding of the learning, as they learned a lot through different customer projects in the programme. Additionally, the students experienced uncertainty coming from outside the Polytechnic, particularly from prospective corporate customers. In Namibia, companies and organisations are not familiar with students approaching them as a team of entrepreneurs, and so, at first, the students had problems convincing their potential corporate customer of their professionalism, since their status was still that of a student. However, the psychological safety that the students gradually felt as part of the team and together overcoming many obstacles and pressures outside the programme made the team a strong unit. The students felt increasingly stronger together as they learned to trust each other and received each other's sincere support. The multiple learning experiences and the use of different learning tools helped the students to understand and see different angles of team learning, as well as to recognise the advantages of this kind of learning:

\footnotetext{
"Because, back in the days, I was always trying to find reasons not to do something, always trying to see the bad things - why can so many things I think go wrong, instead of how many things can go right - if I do it. So, now I think risk is part of life - so we just have to embrace it. The sooner you embrace it the sooner you can create opportunities for yourself, and opportunities will avail themselves to you." (m5)

"I have changed in a sense that before the programme, I always had a doubt about doing things, because I always thought: okay, what will other people say, what's gonna happen if I do this? So, for me it's now just [a matter of] doing it and then, at the end of the day, they see the consequences of the result and bear with that; and if I fail, to me it's not a failure, it's just a learning tool [indicating] that I shouldn't have done it that way, I should've done it in a different way." (m1)

"Now I see it as good, actually. [...] I took a huge risk when I joined this programme. But now that I have seen how we've developed, and how we've come a long way, and how this programme has changed me, I'm actually glad that I took the risk." (f4)

'It has changed me big time. I was afraid of risk. [...] I believe the risk that we took now worked out well, better than we expected. [...] When we changed [to the new programme], I was not sure why I was changing, but I just thought: okay, let me change to entrepreneurship. I thought: okay, you can take a risk-if you fail, fine; you can fall and you stand up and still move on. The entrepreneurs in Namibia, they fail and then they just leave it at that. Because they don't try again, that fear is still in them.' (f1)
}

\section{Strengthening of self-efficacy.}

The students entered the entrepreneurship programme coming from traditional, lecturer-centred programmes, where they had felt that they were being confronted as a class of students rather than as individuals. The students had experienced that their individual voice was not heard during their earlier studies, and hence they were puzzled when they entered the learner-centred programme, about which they felt uncertainty at the beginning. However, in the entrepreneurship programme, they felt that they would have a safe environment in which to learn to practice the work of 
entrepreneurs. Different successes and failures during their entrepreneurship studies taught the students to trust themselves and to gradually realise that they can achieve their goals and succeed as entrepreneurs. The support and trust of the team coach and of teammates was perceived to be very important in strengthening their self-efficacy and self-confidence. The weekly team meetings with constant dialogue and regular, open and honest feedback given each other seemed to also play an important role in strengthening self-efficacy. At the beginning of their entrepreneurship studies, the students each drafted their own personal learning contract, with their own personal learning goals. These contracts were regularly discussed and reflected upon with the coach, and when a student noticed that he or she had improved in a particular skill or ability this was also experienced as the strengthening of the student's self-efficacy.

The following example quotes illustrate this theme:

'If it wasn't for the team, I wouldn't be where I am now. I really, really appreciate what has happened in the past years - it was worth it, and it made me stronger.' (f3)

'It has set me on a new course. It has really enlightened me. It has opened up the way I think, the way I see things, the way I do things. It has enabled me to come out of my box, out of my shell. And so, okay, instead of doing it in a certain manner that, you know, is correct, like the traditional way, you can actually see yourself differently and not be scared to, you know, want to encourage things or come up with things.' (f5)

'I felt that I needed to prove more to my team. I felt that if these guys trust me, I really need to work extra hard, because they really believe in what I call this dream-but they wanted to make it a reality for me. And that's why, until today, I'm doing consultations in marketing and events; and it was because of this team that today I can go walk up to a company and say: listen, I want to do abc with you guys.'(f1)

'I've learned so much about myself that I didn't know - I had talents that I've never used — because of the team.' (f3)

'The first thing that I'm proud of myself regarding this programme is self-confidence. Before I joined this programme, my self-esteem was not very high. But when I joined this programme, I learned a lot from my team and team members regarding team dynamics. It really built up my selfconfidence.' (m7)

\section{Strengthening of team-efficacy}

When the Namibian students started their entrepreneurship studies, before the forming of their team's company, many of them did not know each other. After several months of common team studies, many of them reported the team being a solid unit, together striving ahead to reach common goals. Instead of putting their personal goals and wishes first, they started to consider what would be the best for the team, how to best reach their common goals. They also felt that as a unit of 13 team members, compared to on their own, they better managed to achieve their goals, to take business risks and to win new projects, especially as they strongly felt that all of the team members were backing each other up. In their weekly team sessions, they learned to give each other constructive feedback, which helped them to learn to trust and respect each other. Furthermore, the pressure and doubts that they felt coming from outside the programme, and also from lecturers, other students, the school's management and prospective customers, were seen to make the team a stronger unit, determined to reach the common goals and prove, as the pilot team, the success potential and uniqueness of the programme. 
During their studies, the students experienced the strength of working as a team and recognized the benefits of learning from each other:

"We are actually forced to listen to one another, communicate with one another and share our ideas. And that, personally, to me is a great motivator, because then I know I'm only as good as my team. So, if the team is not good, I'm not good. That motivates me to make sure the team is brilliant and to make sure the team excels. And that way, I would excel also." (m4)

"And we are getting stronger and stronger as the days go by. The final thing I'm going to say about the team is that I think the success of the team is within the team." (f5)

"Learning with other people: it's much better than learning alone. Because if you're learning with other people, everybody has their own views, you know. So everybody has their own opinion when it comes to a certain subject, or when it comes to a certain topic. So, obviously, having twelve other people giving their views and opinions just broadens your horizon.” (f2)

\section{Understanding of others and other cultures}

The team learning with students representing different ethnic groups, habits and beliefs was perceived as an 'eye-opening' experience by the students of the Namibian entrepreneurship programme as they learned to respect, understand and work with each other. They felt that this helped them a lot when engaged in different workplaces after graduation. The different tribes and ethnic groups all have their own habits, customs and beliefs, which affect their everyday life at work and in schools. Working closely together as a team for two years strengthened the 13 different learners' social relationships, their empathy toward each other, and their capability to understand and work with peers from different tribal backgrounds. The students all felt that they had learned to listen and respect each other and to consider, in many cases, the benefits for the team over those for the individual self. Here are some example quotes pertaining to the fifth theme:

"People say: but what about the cultural diversity, how do you get along? As a team, we have laid that out so that culturally we have surpassed any doubt that anybody has ever had that there will be disagreements. And as a team we have proven that we can come from a traditional degree and come to a totally new degree and make it work, and be the first team to make it work." (f5)

"Every person has their own understanding and their own way of doing stuff. [...] It was a challenge for me with a very high learning curve. [...] Now, when I do something, when I take on a project, I don't look at you and say: you are from Europe, you are from Africa. I look at the qualities that you can bring to this project." (f1)

"You always work where there are people, and this is like a way of teaching you how to accept other people. So, that's exactly what I've learned as a team member. So, everywhere, wherever I go, I think: oh yeah, I've seen this type of character before in my team. So, it's a way of learning about people - it's more like psychology." (f3)

"We were seven different tribes, altogether. At the beginning it was difficult, because you do not know why this person is behaving this way today. But I think that it was very good to be put in a team with people from different cultures, because it broke away all the tribalism, so that we had to say: it does not matter which tribe you come from-as long as you can bring something good to the table, that's more than enough." (f1) 


\section{Relationships between the themes}

The five themes - psychological safety, tolerance of uncertainty, strengthening of self-efficacy, strengthening of team-efficacy, and understanding of others and other cultures - were found to be related and tightly bound to each other. The relationships between the themes are illustrated in Figure 1.

Figure 1. THE RELATIONSHIPS BETWEEN THE THEMES 


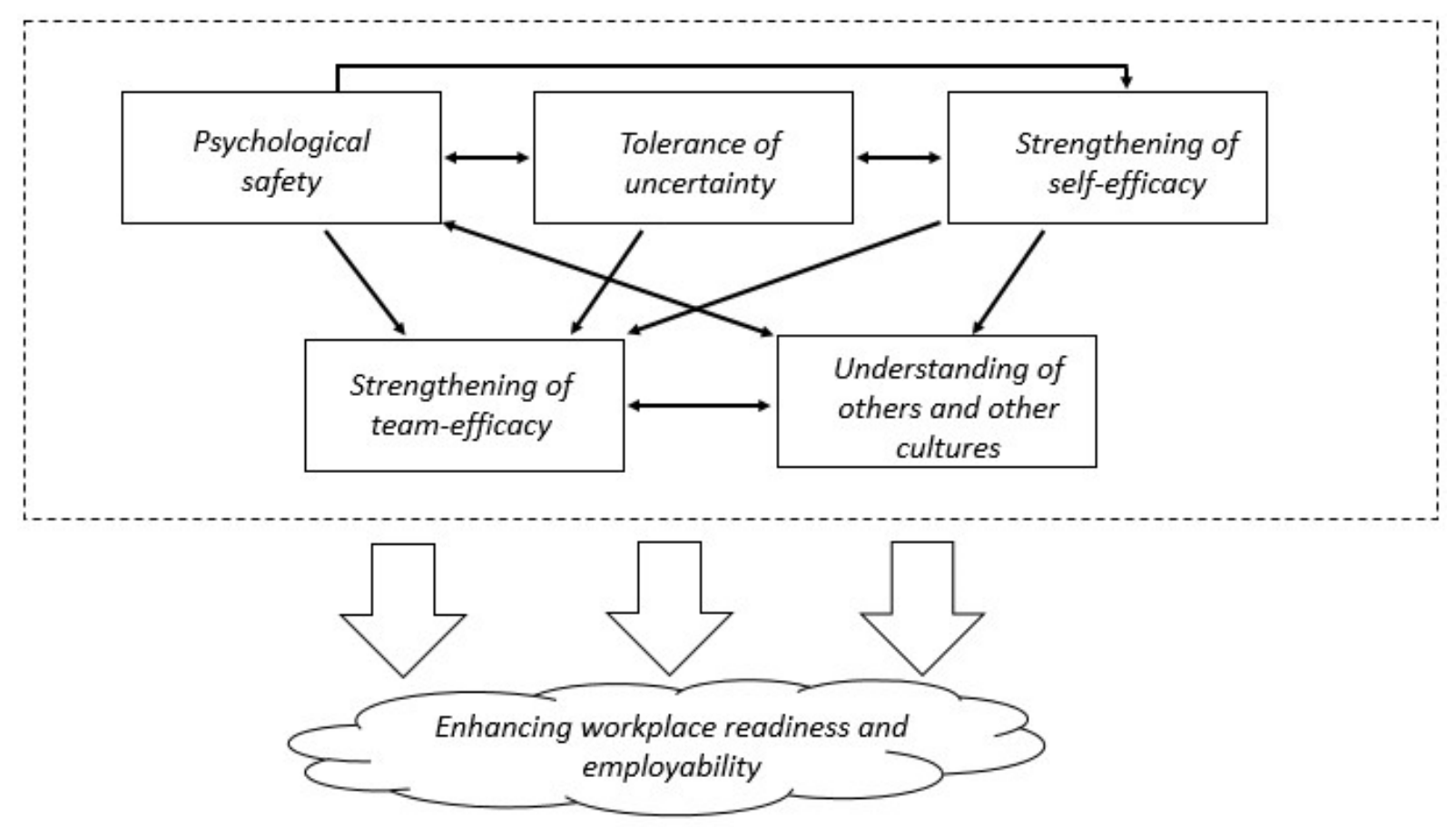

The team's psychological safety had a positive impact on students' tolerance of uncertainty and vice versa, as the following quotes show:

"I think it's truly a great thing to learn in a team, because you have the support of your team, you have the knowledge of the other team members, and you have a support system in a team whether you fail or you make a mistake. And I think that whole support system and community friendshipand all aspects of learning in a team-are great." (m4)

"Team members: they are supporting me every second." (m3)

"The support that we have from the team, that is one of the positives-whatever problem we have. When we have a task that we have to do, as a team we always kind of lift each other up. Even when you are in trouble, you can be having problems, but knowing that there is somebody, there are people out there that really do care about it and give you support with that, it's amazing." (f6)

The element of psychological safety also strengthened team-efficacy and students' self-efficacy, building up beneficial characteristics for entering work life:

"Most difficult, in the beginning, was getting to know each other and working together in a team. But as time progresses, that gets relatively easy. We're at the point that now we can function as one unit and think with one brain, so to speak." (m4)

“My team, yeah, they've inspired me. For instance, in the beginning, like I said, it was hard for me to change some of my old habits, but they never attacked me for it or made me feel bad about it. I was surprised that they actually gave me a lot of support and a lot of encouragement to change, and yeah, hope actually—-so I was able to change." (f4)

As the students learned to understand and work successfully with each other, this also affected the psychological safety of the team and strengthened team-efficacy:

“And I've also learned to really work with people. I've worked with maybe the toughest people in this world, coming together. [...] We started as a group, but it took time to be a team." (m2) 
"I've learned to stand up for my teammates. And they also stand up for me in different situations. We look out for each other, which kind of brought us closer together. I see them more like my brothers and sisters, even though we fight and disagree." (m5)

With the increasingly strong sense of psychological safety and the built-up team-efficacy, the students commented as follows on their improved tolerate of uncertainty:

"If we can make it as a team through this challenge, we can make it through the next." (f4)

'I'm more willing to take risks now that I'm in a team. I think some of the risks I've taken I wouldn't have taken if I didn't have the support of a group of people behind me. So, I think being in a team has helped." (f4)

The theme understanding of others and other cultures was strongly stressed, students' experience of having been part of such a diverse team being considered to be one of the most powerful assets in enhancing the students' workplace readiness and employability in the environment of a developing economy:

"We all consider each other as a family, one family, whatever tribe anyone is from; and at the end of the day, we were like having our own tribe. I think that's also one of the things that we learned from each other, because now even when you go out into the industry, you know that you will be working with different people from different cultural backgrounds." (f6)

"Living in Namibia, we have a lot of tribalism and people judge you according to which tribe you come from. And in our team, we have a lot of different tribes. But what I learned from ProLearning is that it is possible for people of different tribes to work together. And I'm grateful that I've seen a lot of people feel that it's not possible for people from different tribes to work together without it becoming an issue-because I feel like ProLearning has shown me: it is possible!"

Altogether, the five themes seen in students' experiences reflect their perceptions of team learning as a powerful and safe learning environment - a kind of 'playground' - where an open and trusting atmosphere, a network of students and the coaching by the teachers provided a strong base for the students to learn entrepreneurial skills and attitudes, and to enhance their workplace readiness and employability. Indeed, the students had such deep experiences of learning in a team environment that they started to call themselves 'teampreneurs'.

\section{DISCUSSION AND CONCLUSIONS}

The aim of the present study was to develop an understanding of students' experiences of team learning in an entrepreneurship education programme in a developing economy, that of Namibia, where the need of enhancing students' entrepreneurial mindset and working life skills is critical for both personal and national success (World Economic Forum, 2009). The data on the students of the Namibian higher education entrepreneurship programme were collected through semistructured interviews. As a result of the systematic thematic analysis, the students' experiences of learning in and through the team were classified into five main themes: (i) psychological safety, (ii) tolerance of uncertainty, (iii) strengthening of self-efficacy, (iv) strengthening of teamefficacy, and (v) understanding of others and other cultures. The first three themes related to individuals, the fourth related to the team, and the fifth related to wider social relations. The students had to take responsibility for their own learning in this action-based study programme. They had to face new situations, cope with uncertainty, solve problems, find a 
balance between theory and practice, and seek relevant information by themselves. At the beginning of their studies, most of the students felt uncertain and insecure when entering the new and innovative learning environment with new fellow students, since their earlier experience of learning was based on conventional, lecturer-centred teaching. The intensive, two-year team learning in the entrepreneurship programme involved students in sharing and reflecting on their learning experiences together with their peers, as well as in giving open and honest feedback to each other. The findings of the study indicate that the students' team learning yielded various valuable learning experiences that will presumably have positive long-term effects on their lives. When comparing our findings to McKeown's research on entrepreneurial learning in SME (small and medium-sized enterprise) management teams (2010, 2012a, 2012b, 2015), we see many similarities. McKeown's findings can be seen to include elements of all five themes identified in our study: i) psychological safety (McKeown: trust, transparent leadership); ii) tolerance of uncertainty (McKeown: learning from mistakes, trust); iii) combined with iv) strengthening selfand team-efficacy (McKeown: motivation, opportunities, commitment); and v) understanding of others and other cultures (McKeown: trust, sustained and reflective dialogue, listening, transparency of the team). Our findings also indicate that when psychological safety was achieved in the team, the students reported an increase in their tolerance of uncertainty and a strengthening of self- and team-efficacy, which supports Edmondson's earlier (1999) finding that the psychological safety of a team has an influence on its members' learning behavior, which in turn impacts team performance.

In our study, we witnessed that students experienced and recognized the importance of teamwork, as it helped them to cope better with future work life challenges supporting Yazici's similar finding (2005). A key component of this kind of action-based, experiential team learning environment is a community of practice that provides students with the powerful benefit of having such a strong network of honesty and trust. The analysis of the Namibian students' experiences indicates that teamwork did play a major and significant role in learning while establishing their roles within the new and innovative experiential learning environment.

After having practiced their corporate team activities over the period of two years, the students' self-efficacy, entrepreneurial self-efficacy and team-efficacy showed significant improvement. The employment situations of the graduates tells a similar story: shortly after graduation all of the students gained a job, which is remarkable when compared to the fact that $33-64 \%$ of the country's workforce between 15 to 34 years of age were unemployed at the time (Namibia Statistics Agency, 2015). In addition, two thirds of the team members acted as part-time entrepreneurs after graduation. Such a high employment rate $(100 \%)$ following graduation is especially important in Namibia, as well as in other developing economies, where the unemployment figures are exceptionally high.

One of the strongest themes of our study was students' understanding of others and other cultures which reflects the students' increase in empathy toward each other and their capability to understand, trust and work with their peers from different tribal backgrounds. Living in a culturally diverse, multi-ethnic society with different habits and beliefs, the students experienced the tribal issue to be important and significant in their country. According to them, the team learning helped them remarkably in overcoming the issue of tribal differences, and the students experienced strengthened social relationships in the team, resulting in the increased empathy toward each other and the capability to listen, understand and work with peers. One of the students put it like this: "It's glued in your mind, so when you meet another person from the other tribe, the first thing that comes to your mind is: what is he thinking about me? But I really hope that this sort of learning can maybe, in a way, change behaviour or can change behaviours in the country."(f1) This is a very promising result in a globalising world with increasing numbers of immigrants, refugees and asylum seekers, and 
encourages the development of learning environments where multi-ethnic teams strive for shared goals - not only in relation to entrepreneurship education but also in regard to various types of communities in which people work together.

The students in this study reported that the entrepreneurship education had helped them a lot in regard to improving their workplace readiness and employability. These findings have important pedagogical implications for planning similar entrepreneurship education initiatives in other developing economies. The GEM researchers call for a stronger focus on entrepreneurship as a life skill to be taught in schools in order to foster problem-solving skills and self-confidence that will benefit young people (Herrington \& Kelly, 2012). Our study shows how students could be stimulated and encouraged to learn in a new way. From a practical point of view, the outcomes of this study may be utilised in establishing, developing and planning similar entrepreneurship education programmes across different cultural settings in developing economies. Learning entrepreneurship as part of a team is emotionally challenging, but the learning experiences are positive when the support and guidance of the students is well organized (Arpiainen et al., 2013).

Our study suggests that learning entrepreneurship in a team works well, and therefore we recommend team learning to be considered as a key learning environment in entrepreneurship education. The teachers of entrepreneurship education should plan, develop and establish similar entrepreneurship education programmes, where students are encouraged and supported to learn in a team. The students are usually open minded and ready to try different learning environments. If possible, the length of the team learning period should be as long as possible, preferably one to two years, as it usually takes quite a long time to start trusting and respecting each other in a team. Trust and respect within the team members are important key factors to generate the different themes as described in the Figure 1, psychological safety, tolerance of uncertainty, strengthening of self-efficacy, strengthening of team-efficacy, and understanding of others and other cultures, affecting learning. We also suggest to plan and organize student-centered programmes, where students are responsible for their own learning, preferably learning by acting as team entrepreneurs. Making mistakes, failing, learning from mistakes and succeeding all seem to strengthen self-efficacy and team-efficacy, given that the learning environment is supportive. Therefore, we recommend also paying attention to guidance practices and the support system for team learning. One of the strongest themes of our study was students' understanding of others and other cultures. This research result encourages to exploit this kind of team learning model in many different circumstances and situations, where different nationalities, tribes or cultures need to work, understand and accomplish tasks together. Given the lack of qualitative research studies on team-based, experiential entrepreneurship education in developing economies, our study contributes valuable new information with regard to learning in and through teams. Our study was conducted in Namibia, but we believe similar learning results can be achieved in many other developing countries in team-learning environment. Our study also suggests that students learning in a team environment within a developing economy are likely to develop an entrepreneurial mindset and important working life skills, which in turn may enhance students' workplace readiness and employability.

A limitation of the present study is that it is based on a small data set. However, in qualitative studies the saturation point, that is, the point where increasing the number of research participants does not produce any new information, may be as low as seven to eleven participants (e.g. Täks, 2015; Täks et al., 2014). In the present study, the saturation point was reached in the case of the tenth interviewee. Therefore, we trust that the study findings are valid and that they can cautiously be generalized into similar context in developing countries. In particular, we welcome similar 
studies regarding other cultures and cross-cultural comparisons of team-based entrepreneurial learning.

\section{References}

Argyris, C. and Schön, D. (1974). Theory in practice: Increasing professional effectiveness. San Fracisco:Jossey-Bass.

Arpiainen, R-L., Lackéus, M., Täks, M., and Tynjälä, P. (2013). The sources and dynamics of emotions in entrepreneurship education learning process. Trames 17 (67/62) 4:331-346.

Bandura, A. (1986). Social foundations of thought and action, A social Cofnitive Theory. Prentice Hall, Inc. Englewood Cliffs, New Jersey.

Bandura, A. (1997). Self-efficacy: The Exercise of Control. New York, NY: Freeman.

Bandura, A. (2000). Exercise of human agency through collective efficacy. Current Directions of Psychological Science 9:75-78.

Barro, R.J. (2013). Education and economic growth. Annals of Economics and Finance 14, 2:301328

Baumol, W.J. (1968). Entrepreneurship in economic theory. American Economic Review 58, 2:6471.

Barnett, R. (2004). Learning for an unknown future. Higher Education Research and Development 23, 3:247-260.

Baumol, W.J. (1990). Entrepreneurship: productive, unproductive and destructive. Journal of Political Economy 98, 5:893-921.

Braun, V. and Clarke, V. (2006). Using thematic analysis in psychology. Qualitative Research in Psychology 3:77-101.

Bruffee, K. A. (1999). Collaborative learning: Higher education, interdependence and the authority of knowledge. $2^{\text {nd }}$ edition. Baltimore, Johns Hopkins University Press.

Bruton, G.D., Ketchen, Jr.D.J.and Duane Ireland, R. (2013). Entrepreneurship as a solution to poverty. Journal of Business Venturing 28:683-689.

Carrier, C. (2005). Pedagogical Challenges in Entrepreneurship Education, in Kyrö, P. and Carrier, C. (eds.) The dynamics of learning entrepreneurship in cross-cultural university context. Entrepreneurship Education Series 2/2005, Hämeenlinna, Finland, Saarijärven Offset Oy.

Chen, C.C., Greene, P.G. and Crick, A. (1998). Does entrepreneurial self-efficacy distinguish entrepreneurs from managers? Journal of Business Venturing 13, 4:295-316. 
Christensen, C., Johnson, M. and Rigby, D. (2002). Foundations for growth. MIT Sloan Management Review 43, 3:22-32.

Cope, J. (2003). Entrepreneurial learning and critical refection: Discontinuous events as triggers for higher-level learning. Management Learning 34, 4:429-450.

Cope, J. (2005). Toward a dynamic learning perspective of entrepreneurship. Entrepreneurship: Theory and Practice July:373-398.

Cope, J. and Watts, G. (2000). Learning by doing - an exploration of experience, critical incidents and reflection in entrepreneurial learning. International Journal of Entrepreneurial Behaviour and Research 6, 3:104-124.

Deakins, D. and Freel, M. (1998). Entrepreneurial Learning and the Growth Process in SMEs. The Learning Organization 5, 3:144-155.

Deakins, D., O’Neill, E. and Mileham, P. (2000). Executive learning in entrepreneurial firms and the role of external directors. Education and Training 42:317-325.

Decuyper, S., Dochy, F. and Van der Bossche, P. (2010). Grasping the dynamic complexity of team learning: an integrative model for effective team learning in organizations. Educational Research Review 5:111-133.

DeFilippi, R..(2001). Introduction: Project-based Learning, Reflective Practices and Learning Outcomes. Management Learning 32, 1:5-10.

Edmondson, A.C. (1999). Psychological safety and learning behaviour in work teams. Administrative Science Quarterly. June 44:350-383.

Edmondson, A.C., Bohmer, R.M. and Pisano, G.P. (2001). Disrupted routines: Team learning and new technology implementation in hospitals. Administrative Science Quarterly 46:685-716.

Edmondson, A.C. (2002). The local and variegated nature of learning in organizations. Organization Science, 13, 2:128-146.

Edmondson, A.C. (2013). Teaming Innovate. San Francisco, CA: Jossey-Bass.

Eijdenberg, E.L. and Masurel, E. (2013). Entrepreneurial motivation in a least developed country: push factors and pull factors among MSEs in Uganda. Journal of Enterprising Culture 21, 1:19-43.

Fenwick, T. (2003). Innovation: examining workplace learning in new enterprises. Journal of Workplace Learning 15, 3:123-132.

Fink, L.D. (2002). Beyond Small Groups. Harnessing the Extraordinary Power of Learning Teams, in Michaelsen, L.K., Knight, A.B. and Fink, L.D. Team-Based Leanning. A Trasformative Use of Small Groups. Praeger Publishers, Westport, CT.

Gartner, W.B. (1988). Who is an enrepreneur? Is the wrong question. American Journal of Small Business 13, 1:11-32. 
Gartner, W.B. and Vesper, K.H. (1994). Executive Forum: Experiments in Entrepreneurship Education: Success and Failures. Journal of Business Venturing 9, 3:179-187.

Gibb, A. (1987). Enterprise Culture - It's Meaning and Implications for Education and Training. MCB University Press, Bradford.

Gibb, A. (2002a). In pursuit of a new 'enterprise' and 'entrepreneurship' paradigm for learning: creative destruction, new values, new ways of doing things and new combinations of knowledge. International Journal of Management Reviews 4, 3:233-269.

Gibb, A. (2002b). Creating conducive environments for learning and entrepreneurship. Living with, dealing with, creating and enjoying uncertainty and complexity. Industry and Higher Education, June:135-148.

Haidet, P., Levine, R.E., Parmeee, D.X., Crow, C., Kennedy, F, Kelly, A. et al. (2012). Guidelines for reporting team-based learning activities in the medical and health sciences education literature. Academic Medicine 87, 3:292-299.

Hanhinen, T. (2010). Työelämäosaaminen. Kvalifikaatioiden luokitusjärjestelmän konstruointi. Akateeminen väitöskirja. Acta Universitatis Tamperensis 1571. Kasvatustieteiden laitos, Tampereen Yliopisto. Tampere: Tampereen Yliopistopaino Oy - Juvenes Print.

Hemetsberger, A. and Reinhard, C. (2006). Learning and knowledge building in Open-source communities. A social-experiential approach. Management Learning 37, 2:187-214.

Henry, G., Hill, F. and Leitch, C. (2005). Entrepreneurship education and training: can entrepreneurship be taught? Part I. Education + Training 47, 2:98-111.

Herrington, M. and Kelly, D. (2012). GEM African Entrepreneurship. Sub-Saharan African Regional Report.

Honig, B. (2004). Entrepreneurship Education Toward a Model of Contingency-Based Business Planning. Academy of Management Learning and Education 3, 3:258-273.

Hytti, U., Stenholm, P., Heinonen, J. and Seikkula-Leino, J. (2010).Education + Training 52, 8/9: 587-606.

Johannisson, B., Landström, H. and Rosenberg, J. (1998). University training for entrepreneurship an action frame of reference. European Journal of Engineering Education, 23, 4:477-496.

Johnson, D.W. and Johnson, R.R. (1987). Learning together and alone: Cooperative, competitive, and individualistic learning. Englewood Cliffs, NJ: Prentice Hall.

Johnson, D.W., Johnson, R.R. and Smith, K.A. (1991). Cooperative Learning: Increasing College Faculty Instructional Productivity, ASHE-ERIC Higher Education Report 4. The George Washington University, School of Education and Human Development, Washington, DC. 
Kelly, P.A., Haidet, P., Schneider, V., Searle, N., Seidel, C.L. and Richards, B.F. (2005). A comparison of in-class learner engagement across lecture, problem-based learning and team learning using the strobe classroom observation tool. Teaching and Learning in Medicine 17, 2:112-118.

Kolb, D.A. (1984). Experiential learning: Experience as the source of learning and development. Englewood Cliffs, NJ: Prentice Hall.

Koles, P., Stolfi, A., Borges, N., Nelson, S. and Parmelee, D. (2010). The impact of team-based learning on medical students' academic performance. Academic Medicine 85 (11).

Kozlowski, S.W.J. and Ilgen, D.R. (2006). Enhancing the effectiveness of work groups and teams. Psychological Science in the Public Interest 7, 3:77-124.

Krueger, N. Jr. and Dickson, P.R. (1994). How believing in ourselves increases risk taking: perceived self-efficacy and opportunity recognition. Decis. Sci 25, 3:385-400.

Kuratko, D. (2005). The emergence of entrepreneurship education: development, trends and challenges. Entrepreneurship Theory and Practicem 29, 5:577-598.

Kyrö, P. and Tapani, A. (2007). Learning risk-taking competences, in: Fayolle, A. (ed.) Handbook of Research in Entrepreneurship Education Volume 1: 285-310. Great Britain: MPG Books Ltd.

Languages of Namibia (2013). Wikipedia, electronic database, read 6.3.2013.

Lave, J. and Wenger, E. (1991). Situated learning: legitimate peripheral participation, Cambridge University Press.

Leinonen, N., Partanen, J. and Palviainen, P. (2004). The Team Academy - A true story of a community that learns by doing. Juva, Finland.

Lilischkis, S., Volkmann, C., Gruenhagen, M., Bischoff, K. and Halbfas, B. (2015). Supporting the Entrepreneurial Potential of Higher Education European Commission, Final Report. Version 1.1. June 2015.

London, M. and Sessa, V.I. (2006a.) Group feedback processes. Human Resource Development Review 5, 303-329.

London, M. and Sessa, V.I. (2006b). Continuous learning in organizations: A living systems analysis of individual, group and organization learning, in Yammarino, F.J. and Dansereau, F. (eds.) Research in multi- level issues, 5: 123-172. Greenwich, CT: Jai Press.

Lorz, M., Mueller, S., Volery, T. (2013). Entrepreneurship education: a systematic review of the methods in impact studies. Journal of Enterprising Culture 21, 2:123-151.

Maathai, W. (2009). The Challenge for Africa. United Kingdom: William Heinemann.

Man, T. (2007). Understanding entrepreneurial learning A Competency approach. Entrepreneurship and Innovation 8, 3:189-198. 
Martínez, A.C., Levie, J., Kelley, D.J., Sæmundsson, R.J. and Schøtt, T. (2010). Global Entrepreneurship Monitor Special Report: A Global Perspective on Entrepreneurship Education and Training.

McKeown, I. (2010). No More Heroes entrepreneurial learning in the SME management team. Industry \& Higher Education 24, 6:429-441.

McKeown, I. (2012a). Teaching old dogs new tricks: Why underlearning matters in SMEs. The International Journal of Entrepreneurship and Innovation 13, 1:25-34.

McKeown, I. (2012b). Team learning in SMEs: Learning the lessons. Industry and Higher Education 26, 6:491-503.

McKeown, I. (2015). Entrepreneurial learning in small firm management teams, in Rae, D. and Wang, C.L. (eds.) Entrepreneurial Learning. New perspectives in research, education and practice. New York: Routledge.

McMullan, W.E. and Long, W.A. (1987). Entrepreneurship education in the nineties. Journal of Business Venturing 2, 3:261-275.

Michaelsen, L.K. (1983). Team learning in large classes, in Bouton, C. and Garth, R.Y. (eds.) Learning in groups New directions for teaching and learning series, 14. San Francisco: JosseyBass.

Michaelsen, L.K., Black, R.H. and Dee Fink, L. (1996). What every faculty developer needs to know about learning groups, in Bouton, C. and Garth, R.Y. (eds.) To Improve the academy Resources for faculty, instructional and organizational development. Vol. 15. Stillwater, OK: New Forums Press.

Michaelsen, L.K., Bauman Knight, A. and Dee Fink, L. (eds.) (2002). Team-Based Learning. A Trasformative Use of Small Groups. Preface. Praeger Publishers, Westport, CT.

Middleton, J. and Miller, J.C. (2008). New Encyclopedia of Africa Vol. 4: 4-11. Thomson \& Gale. Ministry of Health and Social Services (2001). National policy for reproductive health. Repulic of Namibia electronic publication, read 3.3.2013, http:/www.youth- policy.com/policies/Namibia National Policy for reproductive health.

Minniti, M. and Bygrave, W. (2001). A Dynamic Model of Entrepreneurial Learning. Entrepreneurship Theory and Practice 25, 3:5-16.

Namibia Statistics Agency, 2015. Namibia Labour Force Survey 2014 Report. Namibia Statistics Agency, Windhoek, Namibia.

Namibia Labour Force Survey (2010) Statistics confirmed by the government through the Ministry of Labour and Social Welfare, Namibia.

Nonaka, I. and Takeuchi, H. (1995). The knowledge-creating company. New York: Oxford University Press. 
O'Donnell, A. (2006). The role of peers and group learning, in Alexander, P.A. and Winne, P.H. (eds.) Handbook of educational psychology. Second edition. New Jersey, USA: Lawrence Erlbaum Associates, Inc.

Peltonen, K. (2014). Opettajien yrittäjyyskasvatusvalmiuksien kehittyminen ja siihen vaikuttavat tekijät. Aalto University publication series. Doctoral dissertations 175/2014. Unigrafia Oy Helsinki 2014.

Pittaway, L.and Cope, J. (2007a). Entrepreneurship Education - A Systematic Review of the Evidence. International Small Business Journal 25, 5:479-510.

Pittaway, L. and Cope, J. (2007b). Simulating entrepreneurial learning: Assessing the utility of experiential learning designs. Management Learning 38, 2:211-233.

Pittaway, L., Rodriguez-Falcon, E., Aiyegbayo, O. and King, A. (2010). The role of entrepreneurship clubs and societies in entrepreneurial learning. International Small Business Journal 29, 1:37-57.

Rae, D. (2002). Entrepreneurial emergence: A narrative study of entrepreneurial learning in independently owned media businesses. International Journal of Entrepreneurship and Innovation 3:53-59.

Rae, D. (2005). Entrepreneurial learning: A narrative based conceptual model. Journal of Small Business and Enterprise Development 12, 3:323-335.

Rae, D. (2007). Entrepreneurship from opportunity to action. Palgrave MacMillan, Hamshire, UK.

Rae, D. and Carswell, M. (2000). Using a life-story approach in researching entrepreneurial learning: The development of a conceptual model and its implications in the design of learning experiences. Education + Training 42, 4/5:220-227.

Rae, D. and Carswell, M. (2001). Towards a conceptual understanding of entrepreneurial learning. Journal of Small Business and Enterprise Development 8, 2:150-158.

Raelin, J.A. (1997). Model of Work-Based Learning. Organization Science 8, 6:563-578.

Ryan, G. and Russell Bernard, H. (2003). Techniques to identify themes. Field Methods 15, 1:85109.

Schumpeter, J.A. (1950). Capitalism, Socialism and Democracy, $3^{\text {rd }}$ ed., New York, NY: Harper \& Row.

Senge, P. (1990). The Fifth discipline. London: Doubleday.

Sessa, V.I. and London, M. (2006). Continuous learning: Directions for individual and organization development. Mahwah, NJ: Erlbaum.

Sessa, V.I. and London, M. (2008). Group Learning: An Introduction, in Sessa, V.I. and London, M. (eds.) Work Group Learning. Understanding, Improving \& Assessing How Groups Learn In Organizations. New York.

Suonpää, M. (2010). Local democracy in Keetmanshoop and Ondangwa. Awareness and expectations of the community and stakeholders. Lund University.

Thompson, B.M., Schneider, V.F., Haidet, P., Levine, R.E., McMahon, K.K., Perkowski, L.C. et al. (2007). Team-based learning at ten medical schools: two years later. Medical Education 41, 3:250257. 
Tynjälä, P. (2008). Perspectives into learning at the workplace. Educational Research Review 3: $130-154$.

Tynjälä, P. and Gijbels, D. (2012). Changing world - changing pedagogy, in Tynjälä,P., Stenström, M-L. and Saarnivaara, M.(eds.) Transitions and Transformations in Learning and Education, 205222. Dordrecht: Springer.

Tynjälä, P., Stenström, M-L. and Saarnivaara, M. (2012). Introduction, in Tynjälä, P., Stenström, M-L. and Saarnivaara, M. (eds.) Transitions and Transformations in Learning and Education. Dordrecht: Springer.

Täks, M., Tynjälä, P., Toding, M., Kukemelk, K. and Venesaar, U. (2014).Engineering Students' Experiences in Studying Entrepreneurship. Journal of Engineering Education 103, 4:573-598.

Täks, M. (2015). Engineering students' experiences of entrepreneurship education. A qualitative approach. Dissertationea Pedagogicae Universitatis Tartuensis 18. University of Tartu Press.

Täks, M., Tynjälä, P. and Kukemelk, K. (2016). Engineering students' conceptions of entrepreneurial learning as part of their education. European Journal of Engineering Education 41, 1:53-69.

Umble, E.J., Umble, M. and Artz, K. (2008). Enhancing undergraduates' capabilities through teambased competitions: the Edward Jones Challenge. Decision Sciences Journal of Innovative Education 6, 1:1-27.

Vangrieken, K., Dochy, F., Raes, E. and Kyndt, E. (2015). Teacher collaboration: A systematic review. Educational Research Review 4:15.

Vesalainen,, J. and Strömmer, R. (1998). Teaching Entrepreurship in the University: Methods rather than contents. Proceedings of International Conference Higher Education and SME's. Rennes, France, pp.150-174.

Wood, R. and Bandura, A. (1989). Social cognitive theory of organizational management. Academy of Management Review 14, 3:361-384.

World Economic Forum (2009). Educating the Next Wave of Entrepreneurs: Unlocking Entrepreneurial Capabilities to Meet the Global Challenges of the 21stCentury: A Report of the Global Education Initiative, Switzerland: World Economic Forum.

World Bank report (2015).Namibia. www.worldbank.org/en/country/namibia, read 08.04.2016.

Yazici, H.J. (2005). A study of collaborative learning style and team learning performance. Education + Training 47, 3:216-229.

Young, J. and Sexton, D. (1997). Entrepreneurial Learning: A Conceptual Framework. Journal of Enterprising Culture 5, 3:223-248. 